\title{
Screening of novel restless legs syndrome-associated genes in French-Canadian families
}

Fulya Akçimen, MSc, Dan Spiegelman, MSc, Alexandre Dionne-Laporte, MSc, Ziv Gan-Or, MD, PhD, Patrick A. Dion, PhD, and Guy A. Rouleau, MD, PhD, FRCP(C)

Neurol Genet 2018;4:e296. doi:10.1212/NXG.0000000000000296
Correspondence

Dr. Rouleau

guy.rouleau@mcgill.ca

\section{Abstract}

\section{Objective}

To examine whether any rare, protein-altering variants could be identified across 13 recently identified restless legs syndrome (RLS) loci in familial French-Canadian cases.

\section{Methods}

Whole-exome sequences from 7 large French-Canadian families (4-8 affected per family for a total of 38 cases) were examined for variants in any genes located within $1 \mathrm{Mb}$ on either side of each locus.

\section{Results}

Among the 43 rare protein-altering variants identified, none segregated with RLS in the families.

\section{Conclusions}

Our study does not support a role for causative protein-altering variants in the genes that are located either in the previously or newly identified RLS loci. It is therefore possible that noncoding regulatory variants within these loci or yet unidentified loci could be the cause of RLS in our families.

\footnotetext{
From the Department of Human Genetics (F.A., Z.G.-O., G.A.R.), McGill University; Montreal Neurological Institute (F.A., D.S., A.D.-L., Z.G.-O., P.A.D., G.A.R.), McGill University; and Department of Neurology and Neurosurgery (Z.G.-O., P.A.D., G.A.R.), McGill University, Montréal, Quebec, Canada.

Funding information and disclosures are provided at the end of the article. Full disclosure form information provided by the authors is available with the full text of this article at Neurology.org/NG.

The Article Processing Charge was funded by the authors.

This is an open access article distributed under the terms of the Creative Commons Attribution-NonCommercial-NoDerivatives License 4.0 (CC BY-NC-ND), which permits downloading and sharing the work provided it is properly cited. The work cannot be changed in any way or used commercially without permission from the journal.
} 


\section{Glossary}

ExAC = exome aggregation consortium; RLS = restless legs syndrome; WES = whole-exome sequencing.

As much as $60 \%$ of patients with restless legs syndrome (RLS) have a positive family history, ${ }^{1}$ with a heritability close to $20 \%{ }^{2}$ Using a cohort of 671 cases (192 probands and 479 affected relatives), our team has previously reported that $77.1 \%$ of French-Canadian patients had a family history of RLS, suggesting an important contribution of genetic factors in this population. ${ }^{3}$ In an effort to identify coding variants in the 6 previously identified RLS loci (MEIS1, BTBD9, PTPRD, MAP2K5/SKOR1, TOX3, and rs6747972), we have previously examined 7 French-Canadian families with an autosomal dominant inheritance pattern using whole exome sequencing (WES). Variants were identified in PTPRD and SKOR1, but none of these segregated with the disease in the families studied. ${ }^{4}$ Recently, a large-scale meta-analysis confirmed the 6 loci known to be associated with RLS and identified 13 novel loci. ${ }^{2}$ In the current study, we reanalyzed WES data from the 7 French-Canadian families to examine whether coding variants segregating with RLS could be identified in genes within $1 \mathrm{Mb}$ of all 19 loci.

\section{Methods}

\section{Samples}

Seven French-Canadian families consisting of 32 women (mean age \pm SD: $71.44 \pm 15.23$ years) and 6 men (mean age \pm SD: $70.17 \pm 17.65$ years) were examined using WES (female: male ratio of 5.33:1). All patients were diagnosed according to the International RLS Study Group criteria. ${ }^{5}$ Family pedigrees of probands are shown in figures 1-7.

\section{Standard protocol approvals, registrations, and patient consents}

All subjects provided informed consent, and the study was approved by the respective institutional review boards.

\section{Whole exome sequencing}

WES libraries were prepared using the Agilent SureSelect Human All Exon V4 (Agilent Technologies, Los Angeles, CA) capture kit and sequenced using an Illumina HiSeq2000 platform (100 base pair paired-end sequencing). Reads were aligned to the hg19 human reference genome using the Burrows-Wheeler Aligner tool. ${ }^{6}$ Variant calling was performed using the HaplotypeCaller tool from the Genome Analysis Toolkit v.3.5. ${ }^{7,8}$ Finally, variants were annotated for predicted protein alterations and population frequencies using annotate variation (ANNOVAR). ${ }^{9}$

\section{Variant filtration and segregation analysis}

Only variants that were predicted to be protein-altering (nonsynonymous, splicing, stop-gain) by ANNOVAR were included in the subsequent analysis. Variants were filtered by frequency using the Exome Aggregation Consortium (ExAC) browser, Cambridge, MA (exac.broadinstitute.org, accessed January 2018). Variants below a threshold of 0.05 allele frequency in the non-Finnish European population were included in the final results.

\section{Data availability statement}

The authors confirm that the data necessary for confirming the conclusions of this study are available within the article and its supplementary material. Raw whole exome sequencing data will be provided freely upon request.

\section{Results}

A total of 71 genes within $1 \mathrm{Mb}$ of the 19 loci were found to be screened in 38 affected individuals and a list of candidate variants was established (table e-1, links.lww.com/NXG/A131). The average and minimum coverage of genes screened were $87 \mathrm{x}$

Figure 1 Pedigree of family 1

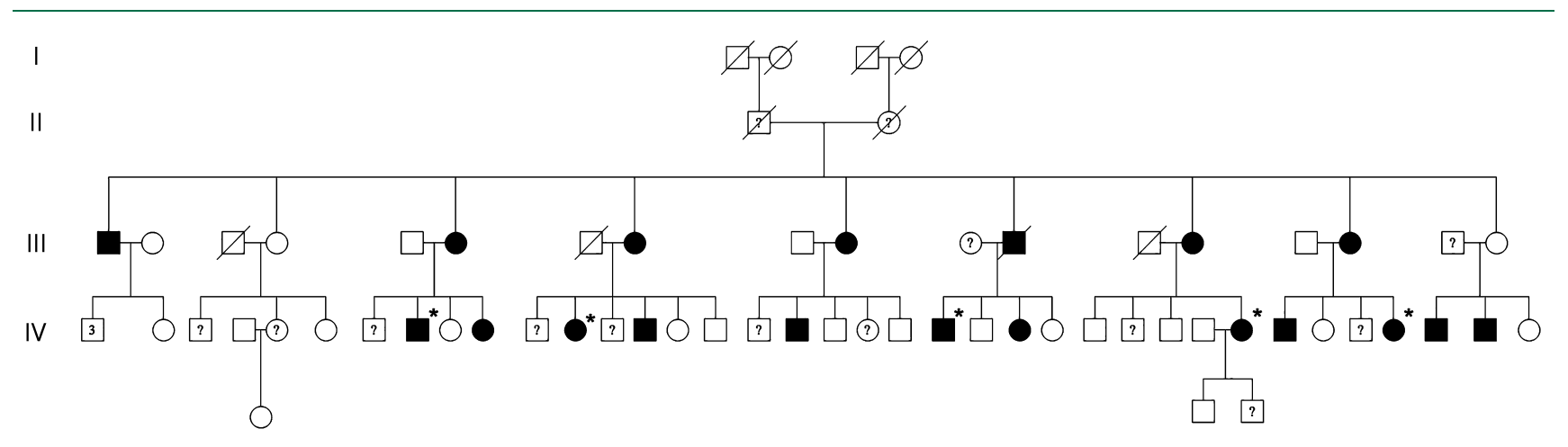

*Exome sequencing data available. 


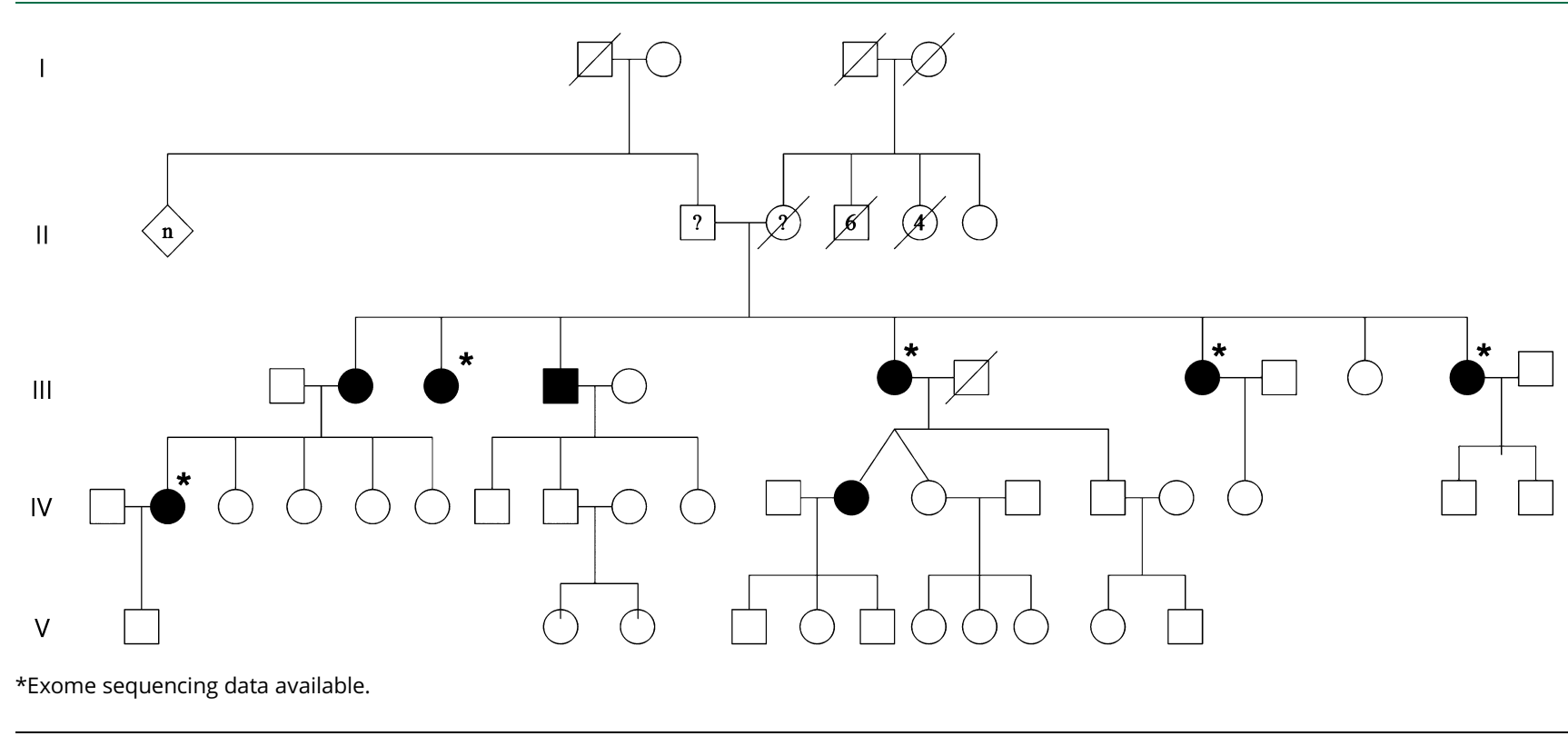

and $25 x$, respectively. A total of 43 variants were predicted to be protein-altering and had a population frequency less than 0.05 . Among the variants identified, none of them segregated well with the disease in pedigrees, which suggests that they are not disease causing.

DNAH8 p.Val874Met (rs45529837, ExAC MAF $=0.03071$ ) appeared to segregate well in one of the families, and as such, it might explain RLS in this family. However, this particular variant was also observed in another family (Family 5: IV$5,6,7$ and V-8) where it did not segregate with the disease.

\section{Discussion}

Our results suggest that nonsynonymous variants within these loci do not explain RLS in these large families and that it is therefore likely that regulatory (coding or non-coding) variants

Figure 3 Pedigree of family 3

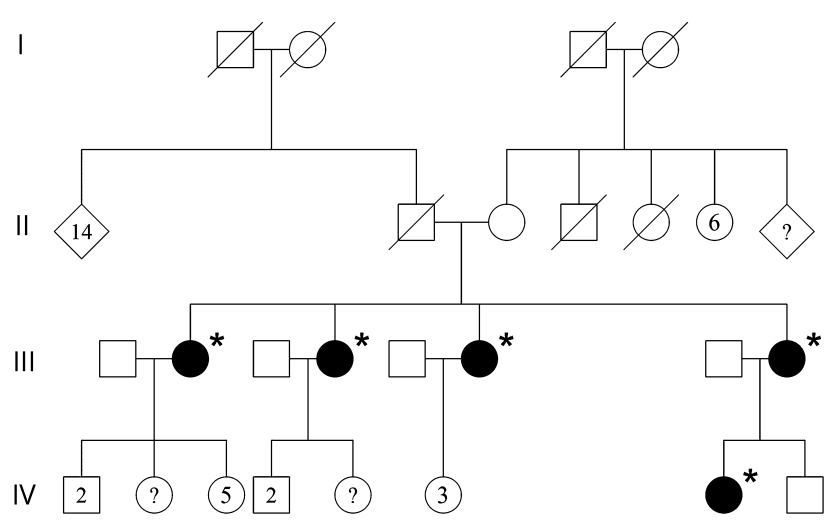

*Exome sequencing data available. are associated with the risk of RLS. While p.Val874Met (rs45529837, ExAC MAF $=0.03071$ ) in DNAH8 (that encodes for an axonemal dynein involved in motility of cilia and flagella $)^{10}$ segregated well in one of the families, it was also observed in another family (Family 5: IV-5,6,7 and V-8) where it did not segregate with the disease, therefore its segregation should be interpreted with caution. Rare causative variants, at much lower frequency than the associated common single nucleotide polymorphism (SNP), can create genomewide associations even when they are megabases away from the common variants that tag them. ${ }^{11}$ A WES approach, like the one used here, can enable the discovery of novel causative variants. The likelihood of achieving this increases with the size of the pedigrees and the penetrance of the condition examined. Although our study does not support a role of rare proteinaltering variants in RLS-associated loci to be a cause of the disease, further studies in more pedigrees are required to determine whether there exist monogenic forms of RLS.

\section{Author contributions}

F. Akçimen: design and conceptualized the study; analysis and interpretation of the data; and drafting the manuscript for intellectual content. D. Spiegelman: analysis of the data. A. Dionne-Laporte: analysis of the data. Z. Gan-Or: drafting or revising the manuscript for intellectual content. P.A. Dion: design and conceptualized the study; interpretation of the data; and drafting or revising the manuscript for intellectual content. G.A. Rouleau: design and conceptualized the study; interpretation of the data; and drafting or revising the manuscript for intellectual content.

\section{Acknowledgments}

The authors thank the patients for their participation in the study. GAR holds a Canada Research Chair in Genetics of the 
Figure 4 Pedigree of family 4

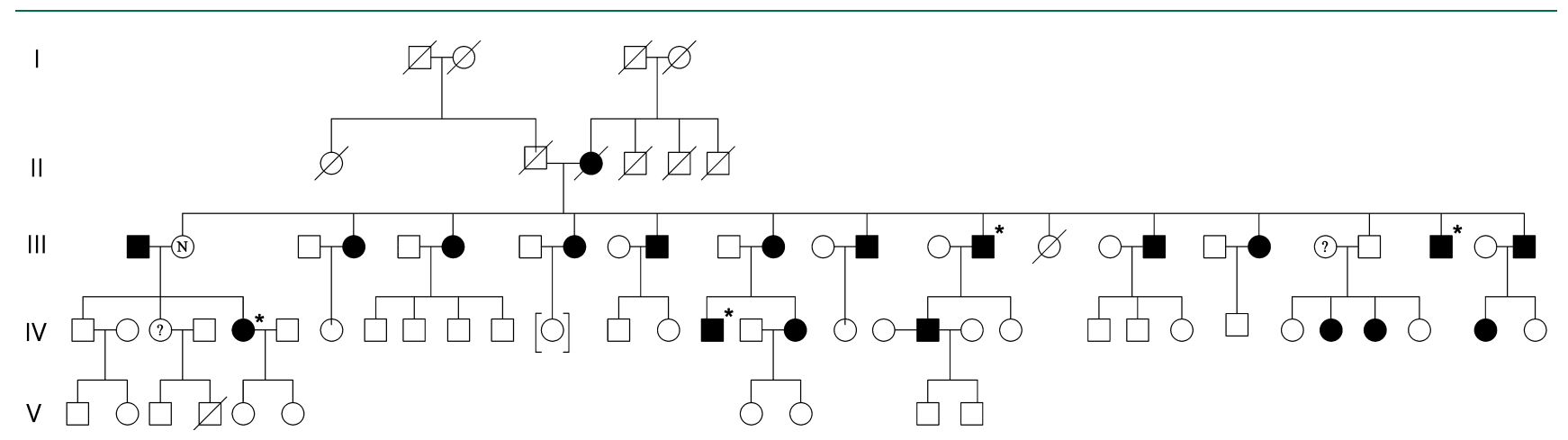

*Exome sequencing data available.

Figure 5 Pedigree of family 5

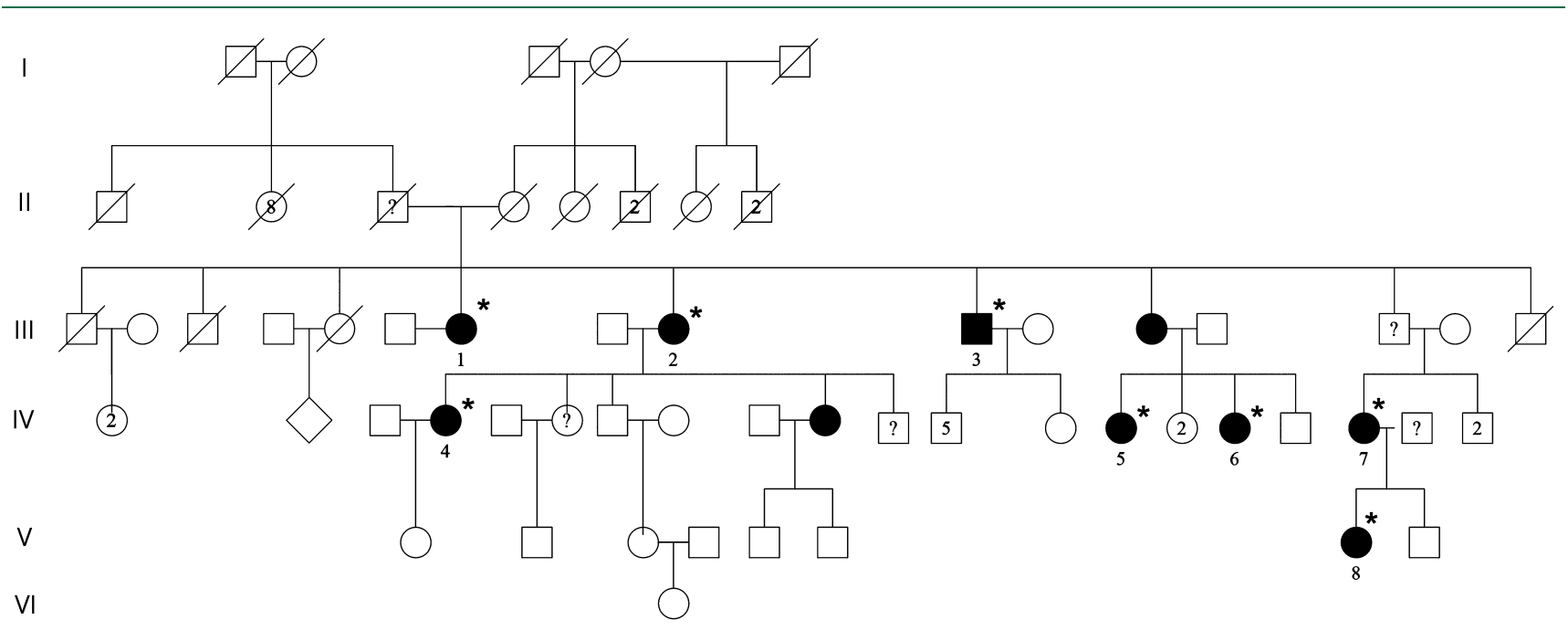

*Exome sequencing data available.

Figure 6 Pedigree of family 6

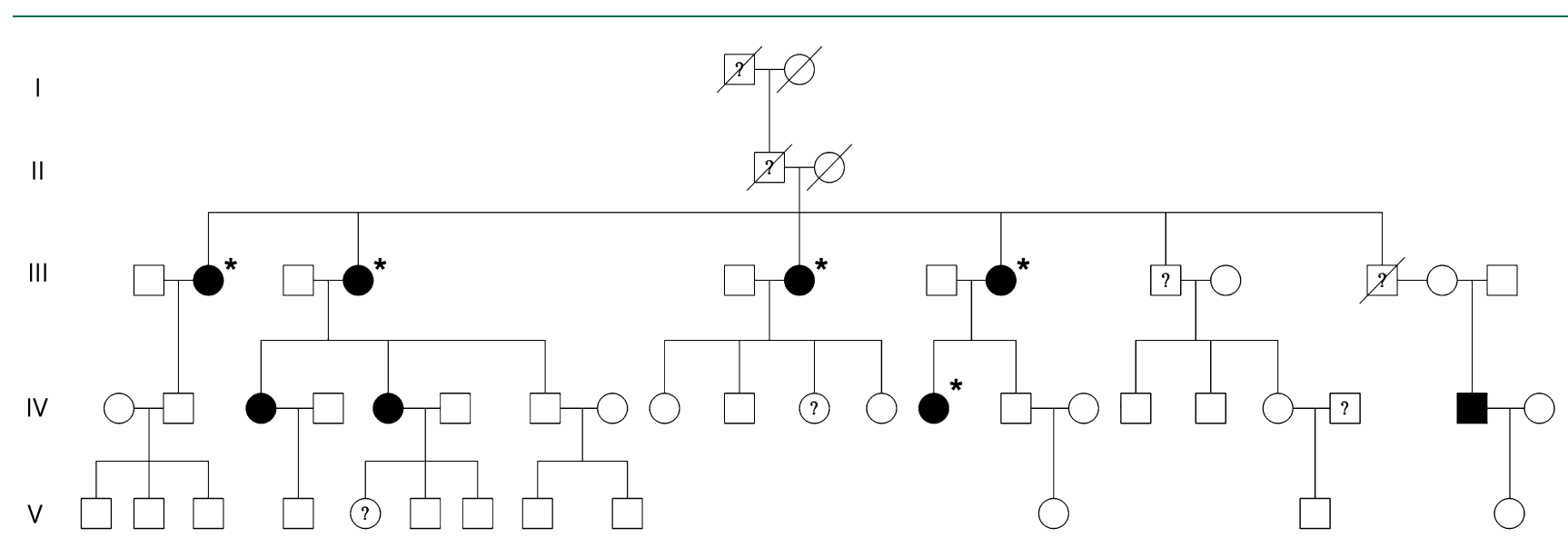

*Exome sequencing data available. 


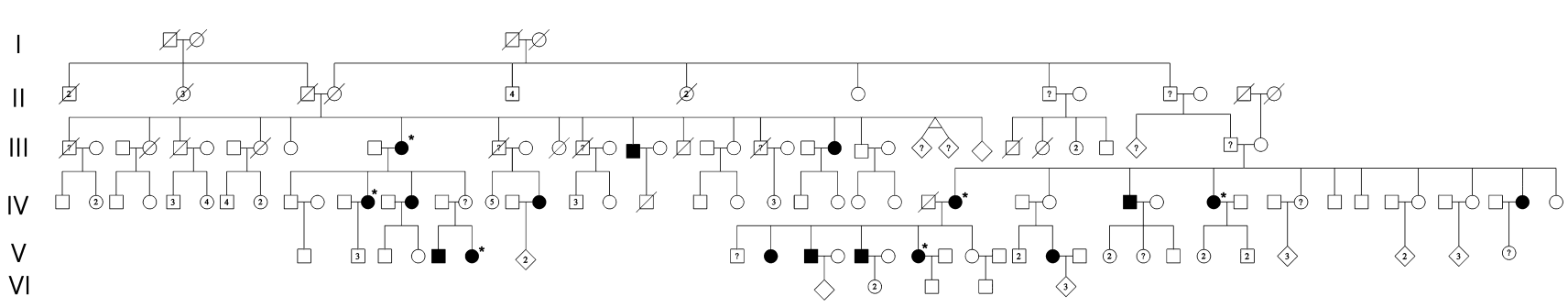

*Exome sequencing data available.

Nervous System and the Wilder Penfield Chair in Neurosciences. The authors thank Jay P. Ross and Cynthia V. Bourassa for their assistance.

\section{Study funding}

No targeted funding reported.

\section{Disclosure}

F. Akçimen reports no disclosures. D. Spiegelman reports no disclosures. A. Dionne-Laporte reports no disclosures. Z. Gan-Or has received funding for travel and/or speaker honoraria from Lysosomal Therapeutics Inc. and Idorsia; serves/ has served on the editorial board of Parkinsonism \& Related Disorders; and serves/has served as a consultant for Lysosomal Therapeutics Inc., Denali, Prevail Therapeutics, Idorsia, and Allergan. P.A. Dion reports no disclosures. G.A. Rouleau has received research support from the Canadian Institutes of Health Research (CIHR), ALS Society of Canada, and the ALS Association. Full disclosure form information provided by the authors is available with the full text of this article at Neurology.org/NG.

\section{Publication history}

Received by Neurology: Genetics June 19, 2018. Accepted in final form October 3, 2018

\section{References}

1. Winkelmann J, Polo O, Provini F, et al. Genetics of restless legs syndrome (RLS): state-of-the-art and future directions. Mov Disord 2007;22(suppl 18): S449-S458.

2. Schormair B, Zhao C, Bell S, et al. Identification of novel risk loci for restless legs syndrome in genome-wide association studies in individuals of European ancestry: a meta-analysis. Lancet Neurol 2017;16:898-907.

3. Xiong L, Montplaisir J, Desautels A, et al. Family study of restless legs syndrome in Quebec, Canada: clinical characterization of 671 familial cases. Arch Neurol 2010;67: 617-622.

4. Gan-Or Z, Zhou S, Ambalavanan A, et al. Analysis of functional GLO1 variants in the BTBD9 locus and restless legs syndrome. Sleep Med 2015;16: 1151-1155.

5. Allen RP, Picchietti DL, Garcia-Borreguero D, et al. Restless legs syndrome/WillisEkbom disease diagnostic criteria: updated International Restless Legs Syndrome Study Group (IRLSSG) consensus criteria-history, rationale, description, and significance. Sleep Med 2014;15:860-873.

6. Li H, Durbin R. Fast and accurate short read alignment with Burrows-Wheeler transform. Bioinformatics 2009;25:1754-1760.

7. DePristo MA, Banks E, Poplin R, et al. A framework for variation discovery and genotyping using next-generation DNA sequencing data. Nat Genet 2011;43: 491-498.

8. McKenna A, Hanna M, Banks E, et al. The Genome Analysis Toolkit: a MapReduce framework for analyzing next-generation DNA sequencing data. Genome Res 2010; 20:1297-1303.

9. Wang K, Li M, Hakonarson H. ANNOVAR: functional annotation of genetic variants from high-throughput sequencing data. Nucleic Acids Res 2010;38: e164.

10. Neesen J, Koehler MR, Kirschner R, et al. Identification of dynein heavy chain genes expressed in human and mouse testis: chromosomal localization of an axonemal dynein gene. Gene 1997;200:193-202.

11. Cirulli ET, Goldstein DB. Uncovering the roles of rare variants in com mon disease through whole-genome sequencing. Nat Rev Genet 2010;11: $415-425$. 


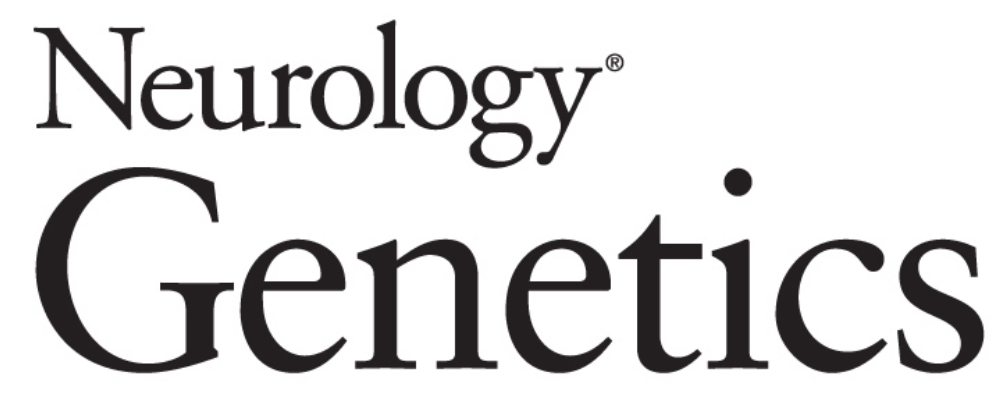

\section{Screening of novel restless legs syndrome-associated genes in French-Canadian families}

Fulya Akçimen, Dan Spiegelman, Alexandre Dionne-Laporte, et al. Neurol Genet 2018;4;

DOI 10.1212/NXG.0000000000000296

\section{This information is current as of December 20, 2018}

\section{Updated Information \&} Services

References

Subspecialty Collections

Permissions \& Licensing

Reprints including high resolution figures, can be found at: http://ng.neurology.org/content/4/6/e296.full.html

This article cites 11 articles, 1 of which you can access for free at: http://ng.neurology.org/content/4/6/e296.full.html\#\#ref-list-1

This article, along with others on similar topics, appears in the following collection(s):

Restless legs syndrome

http://ng.neurology.org//cgi/collection/restless_legs_syndrome

Information about reproducing this article in parts (figures,tables) or in its entirety can be found online at:

http://ng.neurology.org/misc/about.xhtml\#permissions

Information about ordering reprints can be found online: http://ng.neurology.org/misc/addir.xhtml\#reprintsus

Neurol Genet is an official journal of the American Academy of Neurology. Published since April 2015, it is an open-access, online-only, continuous publication journal. Copyright Copyright $\odot 2018$ The Author(s). Published by Wolters Kluwer Health, Inc. on behalf of the American Academy of Neurology.. All rights reserved. Online ISSN: 2376-7839.

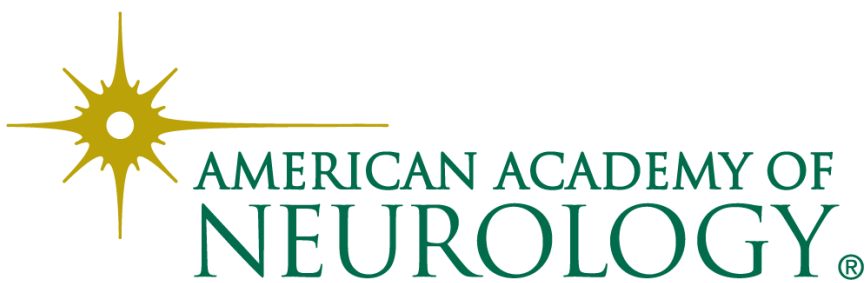

